\title{
The effects of the frequency of participation to the community mental health center on insight, treatment adherence and functionality
}

\author{
Toplum ruh sağlığı merkezine katılım sıklığının içgörü, tedavi uyumu ve \\ işlevselliğe etkisi \\ Sengul Sahin1, Gulcin Elboga2, Abdurrahman Altindag ${ }^{3}$ \\ ${ }^{1}$ Assis. Prof., ${ }^{2}$ Assoc. Prof., ${ }^{3}$ Prof., Department of Psychiatry, Gaziantep University, Gaziantep, Türkiye \\ https://orcid.org/0000-0002-5371-3907-https://orcid.org/0000-0003-3903-1835-https://orcid.org/0000-0001-5531-4419
}

\section{SUMMARY}

Objective: Community Mental Health Centers (CMHC) were established to provide psychosocial support services for patients with severe mental disorders such as bipolar disorder, schizophrenia, unspecified schizophrenia spectrum and other psychotic disorder. The aim of our study was to determine the effects of participation frequency in a $\mathrm{CMHC}$ on insight, treatment adherence and functionality in severe mental disorders. Method: 362 patients diagnosed with bipolar disorder and psychosis according to the DSM-5 criteria and treated in $\mathrm{CMHC}$ were included in this retrospective study. The participation frequency of patients benefited from CMHC services for a year was retrospectively screened. The patients had been evaluated with Clinical Global Impression Scale (CGI), Medication Adherence Rating Scale (MARS), Global Assessment of Functioning (GAF), and Schedule for Assessing the Three Components of Insight (SATCI), and Functional Remission of General Schizophrenia Scale (FROGS). Patients were divided into two groups as bipolar disorder and psychosis (schizophrenia, schizoaffective and USS\&OPD). Results: The patients had been participated in $\mathrm{CMHC}$ services in 6 different frequency groups: 68 (18.8\%) once in six months, $62(17.1 \%)$ once in three months, 68 (18.8\%) once in two months, 98 (27.1\%) once/twice a month, 34 (9.4\%) once/twice a week, $32(8.8 \%)$ three/four times a week, respectively. There were significant differences between GAF, CGI, SATCI, MARS, FROGS scores in terms of participation frequencies of psychosis group and there were significant differences between GAF, CGI, MARS scores in terms of participation frequencies of bipolar disorder group at the end of one year. Discussion: In general, as the participation frequency increased, insight, treatment adherence and functionality increased. In addition to individual factors, our results will also contribute to determine the frequency of participation in CMHC.

Key Words: Community Mental Health, Schizophrenia, Bipolar disorder, Treatment Adherence, Participation Frequency

(Turkish J Clinical Psychiatry 2020;23:64-71)

DOI: $10.5505 / k p d .2020 .49369$

\section{ÖZET}

Amaç: Toplum ruh sağlığı merkezleri (TRSM) bipolar bozukluk, şizofreni ve belirtilmemiş şizofreni spektrumu ve diğer psikotik bozukluklar gibi ağır ruhsal bozukluklarda hastalara psikososyal destek hizmetleri vermektedir. Bu çalışmanın amacı TRSM'ye katılım sıklığının ağır ruhsal bozukluklarda içgörü, tedaviye uyumu ve işlevsellik üzerindeki etkilerini belirlemektir. Yöntem: Çalışmaya, DSM - 5 tanı kriterlerine göre bipolar bozukluk ve psikoz tanısı alan ve TRSM'de takip edilen 362 hasta dahil edildi. Bir yıl boyunca TRSM hizmetlerinden yararlanan hastaların katılım sıklığı retrospektif olarak tarandı. Hastalar Klinik Global İzlem ölçeği (KGi), Tıbbi Tedaviye Uyum Oranı Ölçeği(TTUOÖ), Genel İşlevsellik Değerlendirmesi Ölçeği (IGD), İçgörünün Üç Bileşenini Değerlendirme Ölçeği (IDÖ) ve Şizofreni Hastalarında İslevsel İyileşme Ölçeği (ŞiLÖ) ile değerlendirilmiştir. Hastalar bipolar bozukluk ve psikoz (şizofreni, şizoaffektif, diğer psikotik bozukluklar) olarak iki gruba ayrılarak ayrıca değerlendirilmiştir. Bulgular: Hastalar katılım sıklığına göre 6 farklı grupta değerlendirildi. Hastaların 68'i (\% 18.8) altı ayda bir, 62'si (\% 17.1) üç ayda bir, 68'i (\% 18.8) iki ayda bir, 98'i (\% 27.1) ayda bir/iki, 34'ü (\% 9.4) haftada bir / iki, 32'si (\% 8.8) haftada üç/dört kez TRSM'ye katılım sağlamışlardı. TRSM'ye kayıtlı hastaların klinik değerlendirmelerinde ortalama başlangıç ölçek puanları KGi 4.11, IGD 48.17, iDÖ10.26, ŞiLÖ 45.29, TTUOÖ 5.93 olarak hesaplandı. Bir yılın sonunda, KGi, iGD, iDÖ, şiLÖ, TTUOÖ ölçekleri sırasıyla 3.42, 58.57, 13.12, 55.06, 7.94 olarak hesaplandı. Psikoz grubunda katılım sıklıklarına göre KGi, IGD, iDÖ, şiLÖ, TTUOÖ ölçekleri arasında bir yıl sonunda anlamlı farklııı vardı. Bipolar bozukluk grubunda katılım sıklıklarına göre bir yıl sonunda GAF, KGi, TTUOÖ ölçekleri arasında anlamlı fark vardı. Sonuç: Genel olarak katılım sıklığı arttıkça içgörü, tedaviye uyum ve işlevselliğin arttığı gözlendi. Bu çalışma ağır ruhsal bozukluklarda bireye özgü faktörlere ek olarak içgörü, tedaviye uyum ve işlevsellikte iyileşme sağlamak için, TRSM'ye katılım sıklığının belirlenmesine katkıda bulunacaktır.

Anahtar Sözcükler: Toplum Ruh Sağlığı Merkezi, Şizofreni, Bipolar Bozukluk, Tedavi Uyumu, Katılım sıklığı 


\section{INTRODUCTION}

Psychosocial interventions in chronic psychiatric disorders may have long-term effects on symptom recurrence, insight, quality of life and re-hospitalization rates (1). In this context, educational programs have been developed for both patients and their families, and the knowledge and attitudes of the patients and their relatives about the disorder are reviewed. An appointment reminder and coordinator member of the health care team is likely to improve the treatment adherence with multidimensional implementation strategies such as educational materials or meetings (2). However, it should be noted that the use of these intervention hospitals are challenging. Healthcare personnel may not be well-educated to perform the intervention. These interventions must be performed for about 9/12 months, and there may not be enough resource to adequately deliver and evaluate those $(3,4)$. It may be useful to gather the patients with the same diagnosis in small hospitals for psychoeducation. In particular, additional non-pharmacologic treatment options have increased due to the fact that medical treatment alone is not capable of providing the desired clinical response in functioning $(3,4)$. For this purpose, the World Health Organization (WHO) recommends the community-based mental health model (5). The development of CMHCs with outpatient clinics in Turkey was one of the main strategies in a 2008 national action plan on mental health. The basis of the community-based mental health model is that CMHCs keep patients on active treatment as an outpatient. These centers were established to provide psychosocial support services for patients with severe mental illness such as bipolar disorder, schizophrenia, and unspecified schizophrenia spectrum and other psychotic disorder (USS\&OPD). Treatment adherence, quality of life and social cognitive functions are impaired in schizophrenia and bipolar disorder $(6,7)$. Therefore, an integrated and multidimensional approach should be used to reduce non-adherence to treatment and increase the quality of life of patients. In patients with chronic mental disorder, psychosocial intervention combined with drug therapy reduces the rate of treatment cessation, decreases the risk of symptom recurrence and improves insight, quality of life and social functioning $(1,8)$. Medical teams of CMHC are composed of psychiatrists, nurses, social workers, psychologists, occupational therapists. After patients are admitted to CMHC, psychotherapy is given to them, and patients along with their relatives are provided with psychoeducation and skill training by teachers assigned by public education centers, taking their needs and capabilities into consideration within the scope of orientation studies. The studies about participation frequencies were mostly on psycho-education frequency, antistigmatization and public awareness $(7,9,10)$. A study found that psychosocial skills training once in two weeks was provided significant contribution in symptoms and functioning in nineteen schizophrenia patients (11). In Turkey, the type and frequency of utilization of the patients in CMHC services are determined by the physician according to the individual-specific conditions. In this context, we could not find a guideline in the literature review.

The aim of this study is to determine the effects of the frequency of participation in CMHC on insight, adherence to treatment, social functions in severe mental disorders such as bipolar disorder, schizophrenia and USS\&OPD.

\section{METHODS}

408 patients diagnosed with bipolar disorder, schizophrenia and USS\&OPD according to the DSM-V criteria and treated in the Seyhan CMHC were included in this retrospective study between November 2015 and November 2016. The patient exclusion criteria were as follows: under 18 years of age, active substance abuse or dependence, dementia, moderate or severe mental retardation, and organic mental disorder. Accordingly, 46 patients were excluded from the study. The approval for the study was obtained from the Ethics Committee. The clinical assessment scales that were carried out every 6 months were compared for the patients enrolled in the CMHC. The scores obtained from the clinical assessment scales were compared in terms of baseline and one year after. Patients, all had been receiving CMHC services in different frequencies for one year period, were divided into following groups: a) three/four times a week; b) once/twice a week; c) once/twice a month; d) once in two months; e) once in three months; f) once in 
six months. In CMHC where the study was conducted, the patients had been subjected to the psychoeducation process for at least every 6 months. Moreover, psychoeducation had been provided in the home environment. The frequency of participation of the patients had been determined by the physician and psychologist according to the severity of the disease. The patients benefited from CMHC every 3 months or more frequently had participated in the collective social activities at CMHC. The patients benefited from CMHC every month or more frequently had participated in daily skill therapies at $\mathrm{CMHC}$. The patients benefited from CMHC every week had participated in group therapies at CMHC (Table 1). With the appropriate schedules specific to the severity of illness, all patients had been contacted at least every 3 months and the patients had been provided with CMHC services by reminding via phone calls. The patient preferences had been also evaluated while determining the frequency of participation. On the other hand, the patients with negative symptoms, low insight and low treatment adherence had been encouraged to participate in CMHC with family support. The diagnosis was determined to be a confounding factor in terms of frequency of participation. Therefore, patients were divided into two groups as bipolar disorder and psychosis (schizophrenia, schizoaffective and USS\&OPD)

SPSS 21.0 (IBM Corporation, Armonk, New York, United States) software was used in the analysis of variables. Normal distribution of data was assessed with the Shapiro-Wilk test. The Mann/Whitney U Test was used with Monte Carlo results to compare two independent groups with each other according to the quantitative data. In order to compare the categorical variables, The Pearson Chi/Square, Fisher Exact and Fisher/Freeman-Holton tests were used and provided with Monte Carlo and Exact results. ANOVA (w/Blocks) analysis was used to compare the intergroup changes. The
ANCOVA model was used to examine the covariance effect of continuous variables. Post-hoc (Tukeylards Grouping) analysis techniques were used in order to understand which groups were differentiated. Statistical significance for all cases was determined as $p=0.05$. The variables were analyzed at a confidence interval of $95 \%$ and a $p$ value of $<0.05$ was accepted as statistically significant.

\section{Assessment Instrument}

Clinical Global Impression Scale (CGI-S): CGI-S scale is a single-item scale that involves scoring psychopathology from 1 to 7 so as to assess the general (global) severity of the disorders (12).

Medication Adherence Rating Scale (MARS): MARS evaluates the drug use behavior of the patient during the previous week. The questionnaire consists of 10 questions and the answer "no" for questions 1-6 and 9-10 and the answer "yes" for questions 7-8 indicates adherence to treatment (13).

Global Assessment of Functioning (GAF): GAF is a numeric scale (1 to 100) that evaluates the functioning of the patient from severely impaired to extremely high functioning in 10-point intervals (14).

Schedule for Assessing the Three Components of Insight (SAI): This scale is applied by the clinician and assesses insight quantitatively in accordance with three components consisting of adherence to treatment, being aware of the disease and correctly recognizing psychotic experiences. The prepared 7item schedule for assessing the three components of insight was translated to Turkish by 2 researchers and the scale created by adding 2 items was used. Higher patient score indicates higher level of insight. The reliability and validity study of this

Table 1. CMHC programme according to frequency of participation

\begin{tabular}{lllllll}
\hline Programme in & three/four & Once & Once & once in & once in & once in \\
CMHC/participation & times a & /twice a & /twice a \\
frequency & week & week & month & $\begin{array}{l}\text { two } \\
\text { months }\end{array}$ & $\begin{array}{l}\text { three } \\
\text { months }\end{array}$ & $\begin{array}{l}\text { six } \\
\text { months }\end{array}$ \\
\hline psychoeducation & + & + & + & + & + & + \\
\hline Collective social activities & + & + & + & + & + & - \\
\hline Daily skill therapies & + & + & + & - & - & - \\
\hline Group therapies & + & + & - & - & - & - \\
\hline Reminding via phone calls & + & + & + & + & + & + \\
\hline
\end{tabular}


The effects of the frequency of participation to the community mental health center on insight, treatment adherence and functionality

scale in Turkish was conducted $(15,16)$.

Functional Remission of General Schizophrenia Scale (FROGS): It consists of 19 items in total, each of which is scored from 1 to 5 points in five domains ("Daily Life", "Activities", "Quality of Adherence" "Relational Life", "Health and Treatment") used for assessing the disease (17). The scale has 4 subscales, namely, social functioning, health and treatment, daily life skills, and occupational functioning. Reliability and validity study in Turkish was conducted (18).

\section{RESULTS}

A total of 362 patients were included in the study: 159 (43.9\%) schizophrenia, 35 (9.7\%) schizoaffective disorder, 105 (29\%) bipolar disorder and 63 (17.4\%) unspecified schizophrenia spectrum and other psychotic disorder (USS\&OPD) patients. The patients had been participated in the CMHC services in 6 different frequency groups: 68 (18.8\%) once in six months, $62(17.1 \%)$ once in three months, 68 (18.8\%) once in two months, 98 $(27.1 \%)$ once/twice a month, $34(9.4 \%)$ once/twice a week, $32(8.8 \%)$ three/four times a week, respectively. The mean age of the patients was 41.46 years, the mean duration of disease was 23.41 years and the mean number of hospitalization was 5.78. The frequency groups were composed of 224 $(61.9 \%)$ males and 138 (38.1\%) females. There were no significant differences between the groups in terms of duration of disorders onset, number of admissions to hospital, history of alcohol consumption, smoking and substance abuse, diagnosis distribution and ECT history. The sociodemographic data of the patients are shown in Table 2.

There was a significant association between age, marital status and sex with participation. There was no significant difference between the mean age of the patients who had been participated three/four times a week and once/twice a week $(\mathrm{P}=0.405)$; there was a statistically significant difference between the mean age of the patients who had been participated three/four times a week and once/twice a month, once in two months, once in three months, once in six months, respectively ( $\mathrm{p}$ $<0.05)$.

There was no statistically significant difference between FROGS1 $(\mathrm{P}=0.44)$ and CGI1 $(\mathrm{P}=0.056)$ scales of psychosis group in terms of participation frequencies. There was statistically significant difference between GAF1 $(\mathrm{P}=0.02)$, MARS1 $(\mathrm{P}=0.01)$, SAI1 $(\mathrm{P}=0.01)$, GAF2 $(\mathrm{P}=0.01), \mathrm{CGI} 2$ $(\mathrm{P}=0.01)$, MARS2 $(\mathrm{P}=0.01), \mathrm{SAI} 2(\mathrm{P}=0.01)$, FROGS2 $(\mathrm{P}=0.01)$ scales of psychosis group in terms of participation frequencies. Comparison between groups with mean assessment scores are shown in Table 3.

There was no statistically significant difference between GAF1 $(\mathrm{P}=0.21)$, CGI1 $(\mathrm{P}=0.21)$, SAI1 $(\mathrm{P}=0.62)$, MARS2 $(\mathrm{P}=0.71)$ scales of bipolar disorder group in terms of participation frequencies. There was statistically significant difference between MARS2 ( $\mathrm{P}=0.04)$, GAF2 ( $\mathrm{P}=0.01)$, CGI2 $(\mathrm{P}=0.01), \mathrm{SAI} 2(\mathrm{P}=0.04)$ scales of bipolar disorder group in terms of participation frequencies. Comparison between groups with mean assessment scores are shown in Table 4.

Table 2. Sociodemographic data of patients

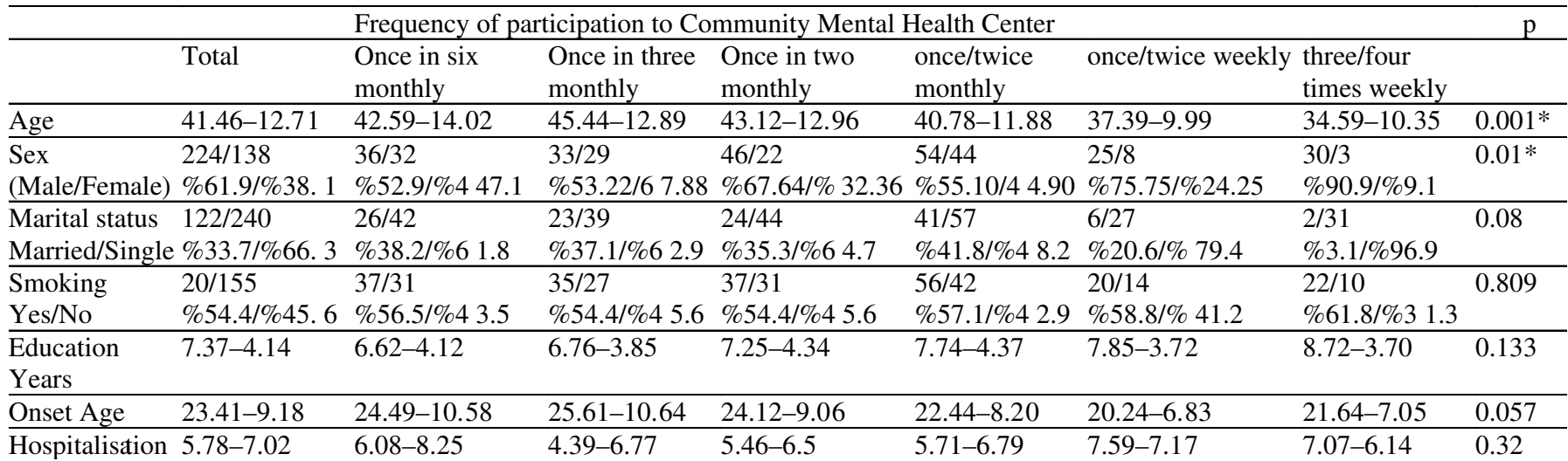


Sahin S, Elboga G, Altindag A.

Table 3. Comparison between assessment scales in terms of participation frequency in psychosis group

Adjusted Mean - SD

Tukey's Grouping

\begin{tabular}{|c|c|c|c|c|c|c|c|}
\hline $\begin{array}{l}\text { Participati } \\
\text { on } \\
\text { frequency }\end{array}$ & A & B & $\mathrm{C}$ & $\mathrm{D}$ & $\mathrm{E}$ & $\mathrm{F}$ & $\begin{array}{l}\text { Significant } \\
\text { differences } \\
\text { between } \\
\text { groups }\end{array}$ \\
\hline GAF1 & $51.0-4.0$ & $46.9-4.1$ & $40.8-2.3$ & $38.4-2.8$ & $45.7-3.1$ & $39.1-3.0$ & $\mathrm{~A} * \mathrm{D}, \mathrm{F}$ \\
\hline CGI1 & $3.8-0.2$ & $4.1-0.2$ & $4.2-0.1$ & $4.6-0.1$ & $4.1-0.1$ & $4.4-0.1$ & No \\
\hline MARS1 & $6.8-0.7$ & $6.9-0.8$ & $5.0-0.4$ & $5.1-0.5$ & $6.2-0.6$ & $4.2-0.5$ & $\begin{array}{l}\mathrm{A} * \mathrm{~F} \\
\mathrm{~B} * \mathrm{~F}\end{array}$ \\
\hline SAI1 & $14.0-1.4$ & $10.8-1.4$ & $8.8-0.8$ & $7.6-0.9$ & $10.3-1.0$ & $7.2-1.0$ & $\mathrm{~A} * \mathrm{C}, \mathrm{D}, \mathrm{F}$ \\
\hline FROGS1 & $48.7-3.8$ & $45.2-4.1$ & $44.9-2.26$ & $39.7-2.73$ & $46.3-3.03$ & $44.5-2.9$ & No \\
\hline GAF2 & $71.9-3.8$ & $65.6-3.8$ & $53.2-2.2$ & $47.0-2.6$ & $50.8-2.96$ & $42.8-2.8$ & $\begin{array}{l}\mathrm{A}^{*} \mathrm{C}, \mathrm{D}, \mathrm{E}, \mathrm{F} \\
\mathrm{B} * \mathrm{C}, \mathrm{D}, \mathrm{E}, \mathrm{F}\end{array}$ \\
\hline CGI2 & $2.8-0.2$ & $3.1-0.2$ & $3.5-0.1$ & $4.1-0.1$ & $3.5-0.1$ & $4.2-0.1$ & $\begin{array}{l}A^{*} \mathrm{D}, \mathrm{F} \\
\mathrm{B} * \mathrm{D}, \mathrm{F} \\
\mathrm{C}^{*} \mathrm{D}, \mathrm{F} \\
\mathrm{E}^{*} \mathrm{~F}\end{array}$ \\
\hline MARS2 & $10.1-0.5$ & $9.1-0.53$ & $7.5-0.3$ & $6.89-0.3$ & $7.6-0.4$ & $5.7-0.3$ & $\begin{array}{l}A^{*} \mathrm{C}, \mathrm{D}, \mathrm{E}, \mathrm{F} \\
\mathrm{B} * \mathrm{D}, \mathrm{F} \\
\mathrm{C}^{*} \mathrm{~F} \\
\mathrm{D} * \mathrm{~F} \\
\mathrm{E}^{*} \mathrm{~F}\end{array}$ \\
\hline SAI2 & $16.1-1.05$ & $15.1-1.07$ & $12.6-0.6$ & $10.9-0.73$ & $12.3-0.8$ & $9.2-0.7$ & $\begin{array}{l}\mathrm{A}^{*} \mathrm{C}, \mathrm{D}, \mathrm{E}, \mathrm{F} \\
\mathrm{B}^{*} \mathrm{D}, \mathrm{F} \\
\mathrm{C}^{*} \mathrm{~F} \\
\mathrm{D} * \mathrm{~F} \\
\mathrm{E}^{*} \mathrm{~F}\end{array}$ \\
\hline FROGS2 & $69-3.8$ & $63.6-4.05$ & $56.3-2.2$ & $46.7-2.6$ & $51.6-2.9$ & $47.3-2.8$ & $\begin{array}{l}A^{*} \mathrm{C}, \mathrm{D}, \mathrm{E}, \mathrm{F} \\
\mathrm{B} * \mathrm{D}, \mathrm{F}\end{array}$ \\
\hline
\end{tabular}

A: Three/four times a week, B: Once/twice times a week, C: Once/twice a month. D: once in two months, E: once in three months, F: once in six months *:There is significant differences between those groups

As a result of the clinical evaluations of all patients who were enrolled in $\mathrm{CMHC}$, the mean baseline scores were calculated as CGI-S 4.11, GAF 48.17, SATCI 10.26, FROGS 45.29, and MARS 5.93. At the end of a year, the CGI-S was calculated as 3.42, GAF 58.57, SATCI 13.12, FROGS 55.06, MARS 7.94 , respectively. There was a significant difference between baselines and 'end of one year' scores in all of these assessment scales (Table 5).

\section{DISCUSSION}

This study investigated the changes in functionality, treatment adherence, and insight according to the frequency of participation with a structured model in the CMHC services among the patients enrolled in CMHC. We evaluated the clinical assessment scales of the patients with schizophrenia, schizoaffective, USS\&OPD, and bipolar disorder that we had been followed up for one year at the baseline and at the end of one year. We investigated the effects of the frequency of participation in the CMHC on insight, treatment adherence and functionality. First finding, there was a significant association between age, marital status, sex and participation frequency. The ratio of male sex was $90.9 \%$ in patients participated three/four times a week, while it was $52.9 \%$ in patients participated once in six months. The female patients with schizophrenia are more active and have a broader social network than the affected males, who are more likely to be harmed by negative symptoms (19). However, a study found that the users of early psychosis services were significantly younger, and more likely to be male, and another study found that male patients with schizophrenia are more likely to visit the mental health rehabilitation unit because of greater disease severity $(20,21)$.

A study from Turkey on the perception of the disease, most of the schizophrenia participants were male (22). In our study, the majority of the participants were young males and they were mainly sing- 
The effects of the frequency of participation to the community mental health center on insight, treatment adherence and functionality

Table 4. Comparison between assessment scales in terms of participation frequency in bipolar disorder group

\begin{tabular}{|c|c|c|c|c|c|c|c|}
\hline & $\begin{array}{l}\text { Adjusted N } \\
\text { Tukey's Gr }\end{array}$ & $\begin{array}{l}\text { an - SD } \\
\text { uping }\end{array}$ & & & & & \\
\hline $\begin{array}{l}\text { Participation } \\
\text { frequency }\end{array}$ & A & B & $\mathrm{C}$ & $\mathrm{D}$ & $\mathrm{E}$ & $\mathrm{F}$ & $\begin{array}{l}\text { Significant } \\
\text { differences } \\
\text { between groups }\end{array}$ \\
\hline GAF1 & $49.5-5.4$ & $55.9-4.8$ & $52.9-2.9$ & $62.6-3.5$ & $51.3-3.5$ & $54.83-3.2$ & No \\
\hline CGI1 & $3.85-0.2$ & $4.4-0.2$ & $3.93-0.14$ & $3.7-0.17$ & $3.8-0.16$ & $3.7-0.1$ & No \\
\hline MARS1 & $6-0.99$ & $5.2-0.8$ & $5.6-0.5$ & $6.9-0.6$ & $8.0-0.6$ & $6.4-0.6$ & $\begin{array}{l}\mathrm{B} * \mathrm{E} \\
\mathrm{C} * \mathrm{E}\end{array}$ \\
\hline SAI1 & $10.1-1.7$ & $11-1.6$ & $11.1-0.9$ & $12.8-1.1$ & $12.2-1.15$ & $10.4-1.08$ & No \\
\hline GAF2 & $75.3-4.6$ & $71.6-4.1$ & $65.6-2.5$ & $70.2-3.0$ & $59.6-2.9$ & $58.4-2.8$ & $\mathrm{~A}^{* \mathrm{~F}}$ \\
\hline CGI2 & $2.59-0.2$ & $3.1-0.2$ & $3.0-0.13$ & $3.02-0.1$ & $3.29-0.1$ & $3.51-0.1$ & $\mathrm{~A} * \mathrm{~F}$ \\
\hline MARS2 & $9.5-0.7$ & $8.3-0.6$ & $8.42-0.4$ & $8.37-0.4$ & $8.5-0.4$ & $7.9-0.4$ & No \\
\hline SAI2 & $14.4-1$. & $14.9-1.1$ & $14.6-0.6$ & $14.8-0.8$ & $14.5-0.7$ & $12.0-0.7$ & $\mathrm{~F}^{*} \mathrm{~A}, \mathrm{~B}, \mathrm{C}, \mathrm{D}, \mathrm{E}$ \\
\hline
\end{tabular}

le. Also these results could be associated with sociocultural norms of our country. There were only three female patients who participated three/four times a week. Two of them were accompanied by one of the family while coming to CMHC.

In terms of functionality, both GAF II scale used in all patients including bipolar disorder and FROGS II scale used only in patients with psychosis showed a significant improvement compared to the baseline scales. Interventions to improve treatment adherence, psychoeducation and other psychosocial interventions, antipsychotic long-acting injections, electronic reminders, and service-based interventions, all have certain evidence in terms of efficacy. Psychosocial interventions using a combination of approaches seem to be more effective than the one-dimensional approaches (23). The day hospitals provide a comprehensive treatment approach that contributes to the early systematic use of all available and effective treatment modalities in the early stages of psychotic disorders. Furthermore, day hospitals aim to obtain and maintain remission and recovery as well as insight and adherence to treatment $(24,25)$. The CMHC include all these methods in all patients with psychosis as well as bipolar disorders.

In patients with schizophrenia, psychosocial intervention combined with drug therapy reduces the rate of treatment cessation and alteration, decreases the risk of recurrence and improves insight, quality of life and social functioning $(1,23)$. In Turkey; Deveci et al. showed that after six months of psychosocial skills therapy (every 2 weeks skills therapy and homework) treatment compliance, treatment efficiency and quality of life have been increased (11). In our study, participation in CMHC activities even once in six months contributed to the illness positively in terms of insight and functioning in all patients.

Active participation of patients in treatment generally increases satisfaction, facilitates treatment adherence and reduces symptom burden in some cases $(11,26)$. If at least participation once per week is considered to be active participation, it is clear that the greatest improvement is achieved in this active group. But there was no significant difference between once/twice week participation and three/four times a week participation according to GAF, FROGS, MARS and SATCI scales in both psychosis and bipolar disorder groups. It is pre-

Table 5. Baseline and one year after scores of the assessment scales in all diagnostic groups

\begin{tabular}{lll} 
& Baseline & End of one year \\
\hline CGI & $4.11-0.97$ & $3.42-0.96$ \\
\hline GAF & $48.17-19.69$ & $58.57-19.05$ \\
\hline SAI & $10.26-6.47$ & $13.12-4.83$ \\
\hline FROGS & $45.29-17.19$ & $55.06-17.64$ \\
\hline MARS & $5.93-3.6$ & $7.94-2.62$ \\
\hline
\end{tabular}

CGI: Clinical Global Impression Scale, MARS: Medication Adherence Rating Scale, GAF: Global Assessment of Func tioning, SAI: Schedule for Assessing the Three Components of Insight, FROGS: Functional Remission of General Schizo phrenia Scale 
dictable that there is no difference in terms of treatment adherence and insight since both groups receive equal number of group therapy, psychoeducation and collective social activities. However, considering that the difference between two groups is only participation in daily skill activities, it is suggested that once/twice week participation is not different from three/four times week participation in terms of increasing the functionality in both diagnostic groups. There were no significant differences between participation frequencies in terms of SAI baseline scores in bipolar disorder patients. But, psychosis patients with high level of insight had a significantly higher participation such as three/four times a week. No such prediction arose in the treatment adherence. A study has found that poor pre-morbid functioning and poor insight predict the medication refusal in psychosis (27). Similarly our results show that poor insight was related to the decrease in participation frequency in psychosis while there was no relation in bipolar group.

A limitation of our study was the lack of a control group consisting of patients getting only outpatient clinic services. Furthermore, there were significant differences between age, marital status, sex and in terms of participation frequency. But the frequency of participation has been linked to the claims of the patients, with the recommendation of the CMHC team and young single male patients preferred to participate in the CMHC services more. It may be posited that patients with better insight/ adherence and lower severity of symptoms might be more motivated to attend the CMHC. However, the patients with negative symptoms, low insight and low treatment adherence had been encouraged to participate in CMHC with a member of his/her family until they got used to coming alone. The role of the CMHC team in determining the frequency of participation is crucial. Another limitation of this study is the low number of participants for each frequency groups.

\section{CONCLUSION}

According to the CMHC participation frequencies, there was a significant difference between the baseline and the end of one year in all clinical assess- ment scales. In general, the frequency of participation associated with insight, treatment adherence, functionality in psychosis group and insight, functionality in bipolar disorder group at the end of one year. It was noteworthy that participation in the activities of CMHC even once in six months with communication at least every three months via phone calls and reminding appointments contributed to the illness positively. No significant difference between once/twice a week participation and three/four times a week participation can be a guide for CMHC medical team to determine the frequency of participation. However, individual variables should be taken into consideration. In addition to individual factors, our results will also contribute to the determination of the frequency of participation with a structured model in the CMHC.

Acknowledgements: The authors acknowledge to Mental Health Center team; Yumusak MM, Gonul N, Kuruoglu H, Boz A, Topal R for assistance with collection of data.

Correspondence address: Assis. Prof. Sengül Sahin, Department of Psychiatry, Gaziantep University, Gaziantep, Türkiyessnglkcmr@hotmail.com 
The effects of the frequency of participation to the community mental health center on insight, treatment adherence and functionality

\section{REFERENCES}

1. Guo X, Zhai J, Liu Z, Fang M, Wang B, Wang C, Hu B, Sun X, Lv L, Lu Z, Ma C, He X, Guo T, Xie S, Wu R, Xue Z, Chen J, Twamley EW, Jin H, Zhao J. Effect of antipsychotic medication alone vs combined with psychosocial intervention on outcomes of early-stage schizophrenia: a randomized, 1-year study. Arch gen psychiatry 2010; 67: 895-904.

2. Girlanda F, Fiedler I, Ay E, Barbui C, Koesters M. Guideline implementation strategies for specialist mental healthcare. Curr Opin Psychiatry 2013; 26: 369-375.

3. Wiedemann G, Hahlweg K, Müller U, Feinstein E, Hank G, Dose M. Effectiveness of targeted intervention and maintenance pharmacotherapy in conjunction with family intervention in schizophrenia. Eur Arch Psychiatry Clin Neurosci 2001; 251: 72-84.

4. Sin J, Gillard S, Spain D, Cornelius V, Chen T, Henderson C. Effectiveness of psychoeducational interventions for family carers of people with psychosis: A systematic review and meta-analysis. Clin Psychol Rev 2017; 56: 13-24.

5. Organization WH. The World Health Report 2001: Mental health: new understanding, new hope. World Health Organization; 2001.

6. Randall JR, Vokey S, Loewen H, Martens PJ, Brownell M, Katz A, Nickel NC, Burland E, Chateau D. A systematic review of the effect of early interventions for psychosis on the usage of inpatient services. Schizophr bull 2015; 41:1379-1386.

7. Mishra A, Krishna GS, Alla S, Kurian TD, Kurian J, Ramesh M, Kishor M Impact of Pharmacist- Psychiatrist Collaborative Patient Education on Medication Adherence and Quality of Life (QOL) of Bipolar Affective Disorder (BPAD) Patients. Front pharmacol 2017; 8: 722.

8. Semahegn A, Torpey K, Manu A, Assefa N, Tesfaye G, Ankomah A. Psychotropic medication non-adherence and associated factors among adult patients with major psychiatric disorders: a protocol for a systematic review. Syst Rev 2018; 7:10.

9. Daumerie N, Vasseur SB, Giordana J, Bourdais CM, Caria A, Roelandt J. Discrimination perceived by people with a diagnosis of schizophrenic disorders. International study of Discrimination and stigma Outcomes (INDIGO): French results. Encephale 2012; 38: 224-31.

10. Sims H, Sanghara H, Hayes D, Wandiembe S, Finch M, Jakobsen H, Tsakanikos E, Okocha CI, Kravariti E. Text message reminders of appointments: a pilot intervention at four community mental health clinics in London. Psychiatr Serv 2012; 63: 9161-9168.

11. Deveci A, Esen-Danaci A, Yurtsever F, Deniz F, Gürlek Yüksel E. The effects of psychosocial skills training on symptomatology, insight, quality of life, and suicide probability in schizophrenia. Turk Psikiyatri Derg 2008; 19: 266-73.

12. Targum SD, Houser C, Northcutt J, Little JA, Cutler AJ, Walling DP. A structured interview guide for global impressions: increasing reliability and scoring accuracy for CNS trials. Ann gen psychiatry 2013; 12: 2.

13. Thompson K, Kulkarni J, Sergejew A. Reliability and validity of a new Medication Adherence Rating Scale (MARS) for the psychoses. Schizophr res 2000; 42: 241-7.

14. Jones SH, Thornicroft G, Coffey M, Dunn G. A brief mental health outcome scale-reliability and validity of the Global Assessment of Functioning (GAF). The Br J Psychiatry 1995; 166: 654-9.

15. David AS. Insight and psychosis. The Br J Psychiatry 1990; 156: 798-808.

16. Arslan S, Günay Kılıç B, Karakılıç H. Assessment of Three Components of Insight reliability and validity. Türkiye'de Psikiyatri 2000; 3:17-24.

17. Llorca P-M, Lancon C, Lancrenon S, Bayle F-J, Caci H, Rouillon F, Gorwood P. The "Functional Remission of General Schizophrenia"(FROGS) scale: development and validation of a new questionnaire. Schizophr Res 2009; 113: 218-25.

18. Emiroglu B, Karadayi G, Aydemir O, Ucok A. Validation of the Turkish Version of the" Functional Remission of General Schizophrenia"(FROGS) Scale. Arch Neuropsychiatry 2009; 46: 15-24.

19. Roy MA, Maziade M, Labbe A, Merette C. Male gender is associated with deficit schizophrenia: a meta-analysis. Schizophr Res 2001; 47: 141-147.

20. Anderson KK, Norman R, MacDougall AG, Edwards J, Palaniyappan L, Lau C, Kurdyak P. Disparities in Access to Early Psychosis Intervention Services: Comparison of Service Users and Nonusers in Health Administrative Data. Can J Psychiatry 2018; 63: 395-403.

21. Petkari E, Mayoral F, Moreno-Küstner B. Gender matters in schizophrenia-spectrum disorders: Results from a healthcare usersepidemiological study in Malaga, Spain. Compr Psychiatry 2017; 72: 136-143.

22. Güner, P. Illness perception in Turkish schizophrenia patients: a qualitative explorative study. Archives of psychiatric nursing, 2014;28:405-412.

23. Cakir S, Ozerdem A. Psychotherapeutic and psychosocial approaches in bipolar disorder: a systematic literature review. Turk Psikiyatri Derg 2010; 21: 143-54.

24. Sago D, Filipcic I, Lovretić V, Mayer N. Day hospital for early intervention for individuals with psychotic disorders. Psychiatr Danub 2018; 30: 192-197.

25. Şahin Ş, Elboğa G. Toplum ruh sağlığı merkezinden yararlanan hastaların yaşam kalitesi, tıbbi tedaviye uyumu, içgörü ve işlevsellikleri. Cukurova Medical Journal, 2019; 44:1-1.

26. O'Connor AM, Stacey D, Entwistle V, Bennett CL, Barry MJ, Eden KB, Holmes-Rovner M, Llewellyn-Thomas $\mathrm{H}$, Lyddiatt A, Thomson R, Trevena L, Wu JH. . Decision aids for people facing health treatment or screening decisions. Cochrane Database of Systematic Reviews 3:CD001 431, 2001.

27. Lambert M, Conus P, Cotton S, Robinson J, McGorry PD, Schimmelmann BG. Prevalence, Predictors, and Consequences of Long-Term Refusal of Antipsychotic Treatment in FirstEpisode Psychosis. J Clin Psychopharmacol 2010; 30: 565-572. 